\title{
Patterns of North African dust transport over the Atlantic: winter vs. summer, based on CALIPSO first year data
}

\author{
Y. Ben-Ami, I. Koren, and O. Altaratz \\ Department of Environmental Sciences and Energy Research, Weizmann Institute of Science, Rehovot, Israel
}

Received: 20 April 2009 - Published in Atmos. Chem. Phys. Discuss.: 15 June 2009

Revised: 11 September 2009 - Accepted: 22 September 2009 - Published: 20 October 2009

\begin{abstract}
One of the most important factors that determine the transported dust effect on the atmosphere is its vertical distribution. In this study the vertical structure of North African dust and stratiform low clouds is analyzed over the Atlantic Ocean for the 2006-2007 boreal winter (DecemberFebruary) and boreal summer of 2006 (June-August). By using the Cloud-Aerosol Lidar and Infrared Pathfinder Satellite Observation (CALIPSO) backscatter measurements over the dust routes, we describe the differences in dust transport between the seasons. We show a bi-modal distribution of the average dust plumes height in both seasons (it is less clear in the winter). The higher plume top height is $5.1 \pm 0.4 \mathrm{~km}$, near the African coast line in the summer and $3.7 \pm 0.4 \mathrm{~km}$ in the winter. The lower plume merges with the marine boundary layer, in both seasons. Our study suggests that a significant part of the dust is transported near and within the marine boundary layer and interacts with low stratiform clouds.
\end{abstract}

\section{Introduction}

Mineral dust has a significant role in the biogeochemical cycles, climatic processes and human life. Dust particles interact directly with electromagnetic radiation and therefore alter the surface-atmospheric radiation budget (Ramanathan et al., 2001; Kaufman et al., 2002; Yu et al., 2006). By serving as clouds drops/ice crystals condensation/freezing nuclei dust may indirectly invigorate convective clouds height (Koren et al., 2005) or accelerate precipitations (Levin et al., 1996), and it can also change clouds lifetime, and albedo (Albrecht, 1989; Hansen et al., 1997; Twomey, 1974; Kaufman et al., 2005a). Solar energy absorbed by dust may change the atmospheric temperature profile and therefore change cloudi-

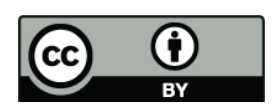

Correspondence to: Y. Ben-Ami (yuval.ben-ami@weizmann.ac.il) ness (Hansen et al., 1997). After sinking or scavenging, dust can supply essential minerals to the biosphere such as in the Amazon rain forest (Swap et al., 1992; Reichholf, 1986; Koren et al., 2006) and phytoplankton in the oceans, hence it may enhance the reduction in atmospheric $\mathrm{CO}_{2}$ (Falkowski et al., 1998) and it can modify the ocean albedo. Dust can also decrease snow and ice albedo and enhance their melting (Psenner, 1999). It may serve as a vehicle for cross oceans transfer of fungi or bacteria, and can be associated with human diseases or oceans catastrophes (Garrison et al., 2003). Nevertheless, our knowledge on basic questions concerning the dust loading (Cakmur et al., 2006) and sink (Tegen, 2003), as well as its chemical (IPCC, 2007; Engelstaedter et al., 2006) and radiative (Haywood and Boucher, 2000) properties, still lack with large uncertainties.

Previous remote sensing studies (e.g. Herman et al., 1997; Prospero et al., 2002; Israelevich et al., 2002; Middleton and Goudie, 2001; Kaufman et al., 2005b) and observations (e.g. Prospero and Lamb, 2003) identified that the North African dust activity is subjected to a strong seasonal cycle. As a consequence, the location of the dust sources, their activity pattern and the transport routes are affected.

The synoptic conditions over West of Africa and the mid Atlantic during the summer months were discussed in details in previous studies (Karyampudi and Carlson, 1988; Karyampudi et al., 1999; Schepanski et al., 2009). The dust outbreaks occur predominantly within the ridge region of passing easterly wave disturbances with a periodicity of 57 days (Prospero and Carlson, 1972). These dust outbreaks occur under the conditions of a thermal low that prevails over West Africa (centered around $17^{\circ}-23^{\circ} \mathrm{N}$ ) in this period (due to intense solar heating). The converging strong low-level flow around the low lifts the dust as a result of strong surface pressure gradient. Over this region there is a deep mixed layer that often extends up to $5-6 \mathrm{~km}$ in height. The airborne dust is carried westward in the Saharan Air Layer (SAL) between 1.5 to $5-7 \mathrm{~km}$ by the prevailing easterly flow in these

Published by Copernicus Publications on behalf of the European Geosciences Union. 
a. Summer

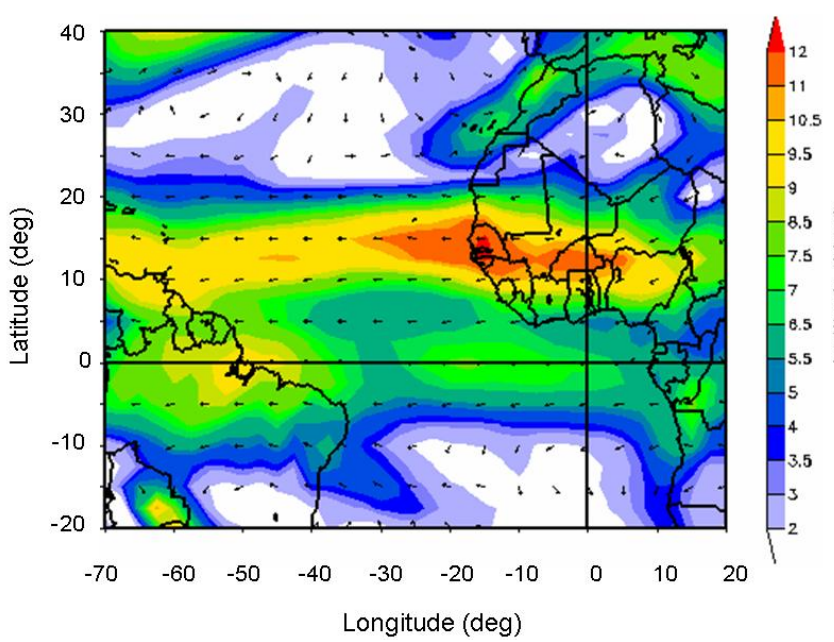

b. Winter

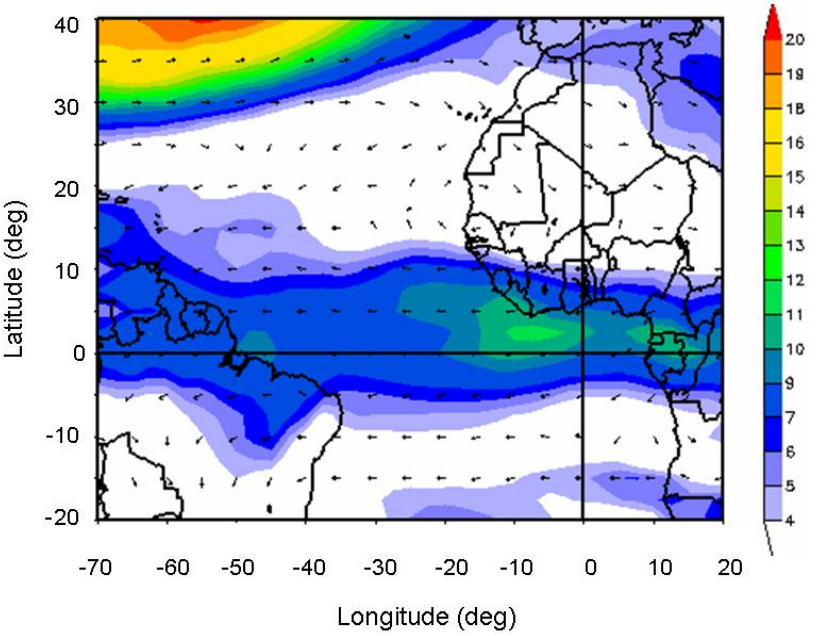

Fig. 1. $700 \mathrm{mb}$ level winds $\left(\mathrm{m} \mathrm{s}^{-1}\right.$ ) for the (a) summer (June-August 2006) and (b) winter (December 2006-February 2007) based on National Center for Environmental Prediction (NCEP) re-analysis.

latitudes (Prospero and Carlson, 1972; Karyampudi et al., 1999; Karyampudi and Carleson, 1988; Prospero and Nees, 1977). Over the ocean, at low level (beneath the SAL), there are relatively clean northeasterly trade winds in the marine mixed layer. The southern equatorial trough or Intertropical Convergence Zone (ITCZ) is located between $5^{\circ}-10^{\circ} \mathrm{N}$. In accordance with the meridional temperature gradient at mid levels heights, between the warm Saharan air and the cooler air in the equatorial zone, there is a strong vertical shear in the zonal wind between 850 and $650 \mathrm{mb}$, that manifests itself as a mid-level easterly jet (Karyampudi and Carlson, 1988). The $700 \mathrm{mb}$ level winds represent this mid-level flow. Figure 1a presents the mean winds in the $700 \mathrm{mb}$ level during the studied summer months. During these months the dust is mainly transported over the Atlantic Ocean towards the southern part of the United States, Caribbean and the north part of South-America. Often, it can be transported northerly by anticyclonic eddies over the Canaries or Azores Islands (Carlson and Prospero, 1972; Kaufman et al., 2005b).

The synoptic condition over the region during the winter months are less discussed in the literature. The synoptic systems move southward compared to the summer (Kalu, 1979; Schepanski et al., 2009) and they are less consistent. The thermal low over Africa has larger variance and is centered on latitudes $5^{\circ}-10^{\circ} \mathrm{N}$. The mid-level jet location is around $5^{\circ} \mathrm{S}-7^{\circ} \mathrm{N}$. Figure $1 \mathrm{~b}$ presents the mean wind direction in the $700 \mathrm{mb}$ height during the studied winter months. The dust is transported south westward, toward the northern part of South America, while crossing the African coastline near the equator (Prospero et al., 2002).

During the winter months the West African Sahelian region is characterized by large areas of biomass burning fires mainly due to agricultural activities. In the same time low level easterly and north-easterly Harmattan winds transport the dust toward the biomass burning regions causing unavoidable external mixing. Ground based and aircraft measurements from the African Monsoon Multidimensional Analyses (AMMA, Formenti et al., 2008), the Dust Outflow Deposition to the Ocean (DODO, Formenti et al., 2008), the SAharan Mineral dUst ExperiMent (SAMUM, Ansmann et al., 2009), and the Dust And Biomass EXperiment (DABEX, Johnson et al., 2008a, b) showed that the winter atmospheric column may contain a multi layers structure of low level dust layer and elevated biomass burning layer that contains dust as well as external mixing of both types of aerosols. Moreover, they estimated the contribution of the dust mass, of elevated biomass burning aerosol layer, to be extremely high ( $72 \pm 16 \%$, Formenti et al., 2008). Therefore, during the winter we describe the transport of plumes of dust-biomass burning aerosol mixture.

Until the launch of CALIPSO, the vertical distribution of dust over the Atlantic Ocean was studied mostly by short term in-situ (e.g. McConnell et al., 2008; Reid et al., 2003) and remote sensing (e.g. Karyampudi et al., 1999) measurements as well as models (e.g. Schepanski et al., 2009). The Cloud-Aerosol LIdar with Orthogonal Polarization (CALIOP) instrument on board the CALIPSO (as a part of the A-Train constellation) has opened an opportunity to study the transported dust vertical structure in a large number of events (sufficient statistics). A few recently published papers used the CALIPSO data to examine the vertical distribution of the dust over the Atlantic Ocean, but only for short term case studies (e.g. Liu et al., 2008a; Generoso et al., 2008). In this study we use the attenuation backscatter measurements, done by the CALIOP instrument on board the CALIPSO (Thomason et al., 2007) for a longer period 


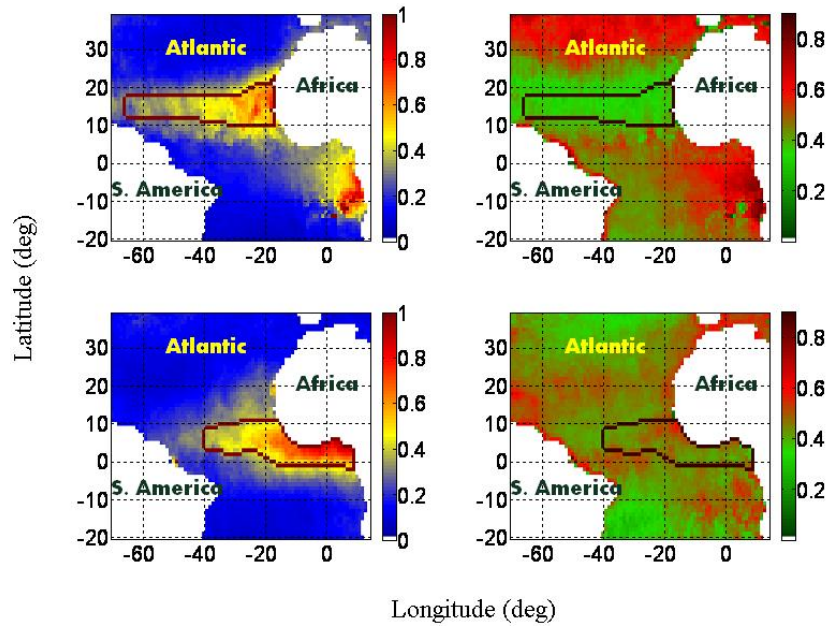

Fig. 2. Aerosol optical properties over the Atlantic Ocean, for the 2006 summer (upper row) and 2006-2007 winter (lower row), from the MODIS instrument onboared Terra. Left column: the aerosol optical depth (at $550 \mathrm{~nm}$ ). Right column: the aerosol fine mode fraction. The contours mark the center of the seasonal plume.

of time. We characterize the average dust vertical distribution in the summer (2006) versus the dust and smoke in the winter (2006-2007) along the main transport route in each season, where the impact of dust upon biogeochemical cycles, climatic processes and human life is the most significant. We also examine the heights of the dust and low stratiform clouds layers in order to understand what type of interaction should be expected there.

\section{Methods}

The measurements made by the CALIOP instrument are three calibrated lidar profiles: total attenuated backscatter at $532 \mathrm{~nm}$ and $1064 \mathrm{~nm}$, and the perpendicular polarization component of the backscatter at $532 \mathrm{~nm}$. The vertical resolution of the $532 \mathrm{~nm}$ and $1064 \mathrm{~nm}$ channels (in the lowest $8.2 \mathrm{~km}$ ) are 30 and $60 \mathrm{~m}$, respectively. Both channels have horizontal resolution of $33 \mathrm{~km}$ (Winker et al., 2007).

The polarization backscatter data attributed from CALIOP instrument can add significant information on aerosol shape and optical properties that can be used for aerosol classification. However, the noise level of most of the attenuated backscatter data was too high for (a) detecting the boundaries of the aerosol layer, and (b) to determining if we see smoke only, dust only or mixture. Classification process, based on this data, could not be robust. Moreover several recent papers suggested that over the ocean most of the aerosol packages are mixed.

For fast classification between aerosol and clouds and in order to mark the top and bottom of the dust layer, we hoped to use either the CALIPSO depolarization product or the Ver-

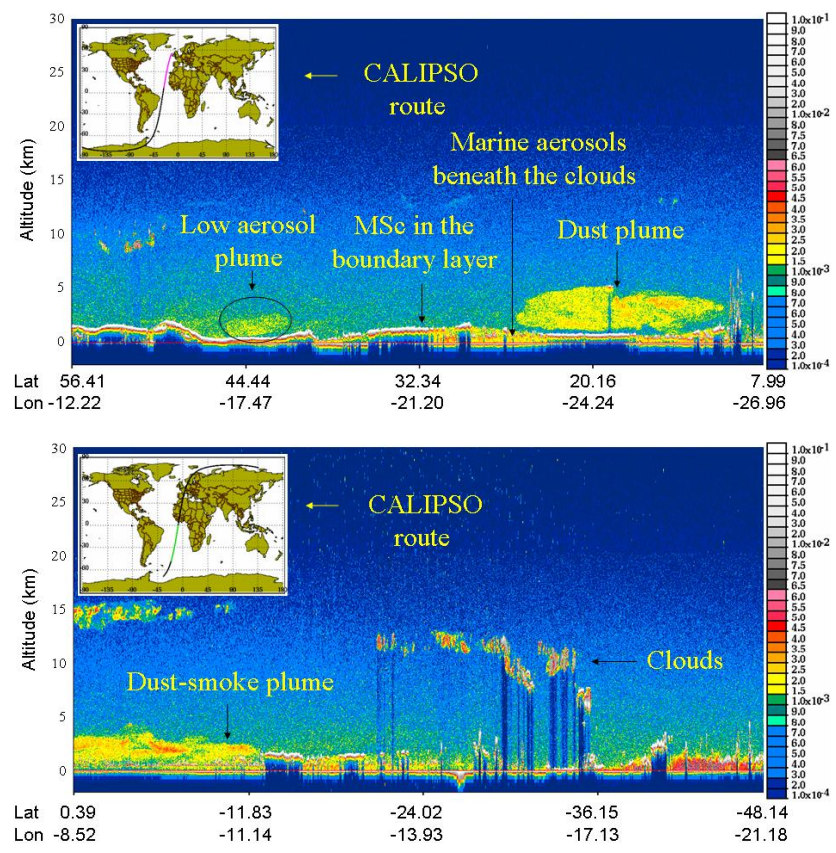

Fig. 3. CALIPSO summer (upper part - 6 July 2006) versus winter (lower part -4 February 2007) nocturnal vertical attenuated backscatter (in $\mathrm{km}^{-1} \mathrm{sr}^{-1}$ ). X-axis: latitude (upper scale) and longitudes (lower scale). The internal figures present the routes of the satellite.

tical Feature Mask (VFM, Vaughan et al., 2005). However we found out that for such detailed analysis the best results are obtained when the final aerosol layer is mask manually on each profile. Due to the high noise level of the attenuated backscatter data (especially backscatter data acquired during daytime), we used the depolarization product and the VFM as the sources for the initial classifications and then we manually determined the location of the aerosol layer. The data was not used, when the confidence level was low. The classification is based on the different backscatter patterns between clouds and aerosol. While aerosol plumes have relative weak but uniform signature, stratiform (low, marine stratocumulus or higher stratus) clouds have a much stronger and narrower backscatter signal and convective clouds has patchy backscatter pattern. The total attenuated backscatter at 532 $\mathrm{nm}$ data has shown the best contrast and served as the main reference data for classification.

The selected research area is between $40^{\circ} \mathrm{N}$ to $20^{\circ} \mathrm{S}$, and $15^{\circ} \mathrm{E}$ to $70^{\circ} \mathrm{W}$, during 2006 summer (June-August) and 2006-2007 winter (December-February). The selection of the study area was based on the dust transport region obtained by the MODIS total Aerosol Optical Depth (AOD) and aerosol fine fraction maps (Kaufman et al., 2005c) and in agreement with the dust distribution in previous studies (e.g. Prospero, 1999; Prospero et al., 2002; Herman et al., 1997; Kaufman et al., 2005b). This wide region covers the main dust transport routes for both seasons. 


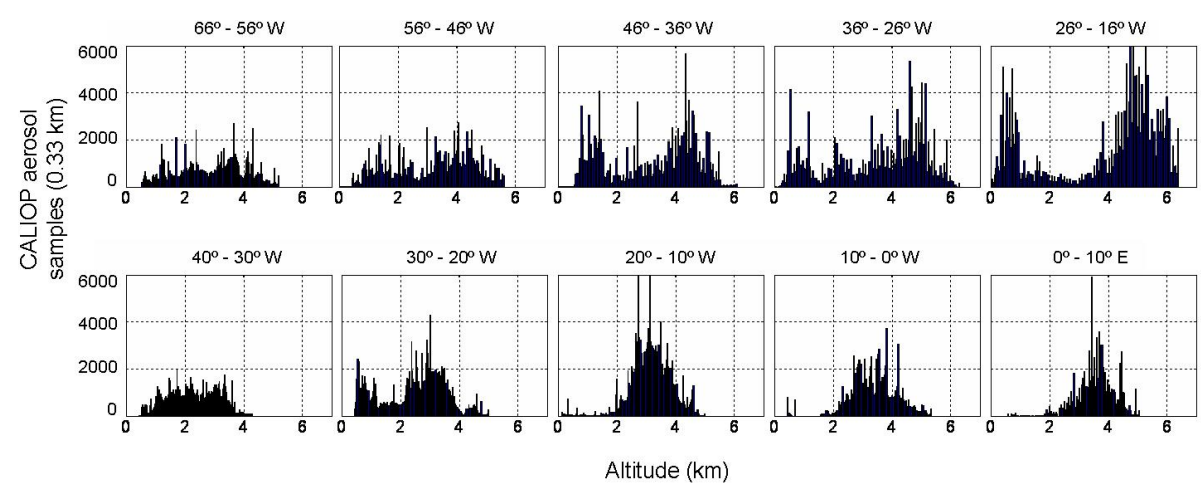

Fig. 4. Aerosol plumes top height distribution (for all CALIOP samples and before excluding the MBL tops) along the center of the plumes (see Fig. 2), for the summer (upper row) and winter (lower row). Each histogram covers an area of $10^{\circ}$ longitudes along the contour line (marked in Fig. 2), starting from the West North African coastline (right) toward the Americas (left). Samples for horizontal intervals of $330 \mathrm{~m}$ along the flight track.

MODIS aerosol fine mode fraction of optical depth is defined as the fraction of the total optical depth attributed to the fine mode (aerosol with diameter smaller than $1 \mu \mathrm{m}$, Kaufman et al., 2005b). The fine mode fraction parameter enables discrimination between dust or sea-salt and pollution or biomass burning aerosols. Dust aerosol is dominated by relatively large particles (diameter larger than $1 \mu \mathrm{m}$ ) and therefore will have a significant coarse mode fraction where the smoke from biomass burning and industrial aerosol are dominated by smaller particles (diameter smaller then $1 \mu \mathrm{m}$ ) and therefore are characterized by the fine mode fraction (Dubovik, et al., 2002).

The summer dust transport route is clearly shown in an area characterized by high AOD levels (contributed mainly from dust but also from marine aerosol) and low fine fraction values (Fig. 2, upper row). The winter dust transport (Fig. 2, lower row) is known to migrate southward to the border of the Sahara and the Sahel region (e.g. Kaufman et al., 2005b), where intensive biomass burning occurs. Therefore the coarse mode contribution of the dust is smoothed by the smoke, resulting in a blurrier coarse mode signature of the dust. Nevertheless, the high AOD (contributed mainly from dust and smoke, but also from marine aerosol) area of the winter flux is shown to have lower fine mode values surrounded by higher fine-fraction contributed by smoke from the southern parts of Africa and Brazil and pollution form North America.

Based on this MODIS data and taking into account the above field experiments results we decided not to distinguish between the dust and the smoke plumes during the winter. Therefore, for the winter analysis, we study the transport of a joint dust-smoke plumes.

For each backscatter vertical profile within the research area the top and the base of the aerosol plumes as well as the location of the low stratiform clouds were picked (the stratiform clouds are often too thin to distinguish between their bases and tops) manually. An example for the differences between the aerosol and cloud signature can be seen in Fig. 3.

When the location of the dust plume base was close to the top of the Marine Boundary Layer (MBL), we couldn't determine its exact location. Therefore, results of plume bases height and thickness (mainly of the lower plumes) may introduce error. Since the daytime measured data has higher level of noise due to the contribution of the solar radiation (Liu et al., 2008b) the aerosol signal in daytime profiles was enhanced by averaging the nearest 5 pixels (total of $1.65 \mathrm{~km}$ ) along the horizontal dimension of the profile. The collected data of aerosol plumes and clouds heights, as well as the MBL depth, for both daytime and nighttime were sorted into $1^{\circ} \times 1^{\circ}$ grid. The data was collected from 381 daytime and 499 nocturnal CALIPSO tracks.

To avoid statistical biases in areas with rare aerosol and clouds measurements, aerosol and cloud grid points with only one daily sample were removed from the dataset. Next, the average heights of the dust and dust-smoke plumes (and clouds) were defined statistically by analyzing the local top height distribution (see a detailed description in Sects. 3.1 and 3.2).

\section{Results}

\subsection{Dust}

Analyzing the aerosol plumes top height distribution reveals a bi-modal distribution in the summer. In the winter distribution there is a dominant dust-smoke high level plumes with a minor peak in lower altitudes (Fig. 4). The low altitude mode in both seasons contains marine aerosol beside the dust. Note that although the MBL depth (often the top of the layer is bounded by marine stratocumulus clouds (MSc), see Sect. 3.2 and Fig. 3) appears in the histograms of the dust 
a.

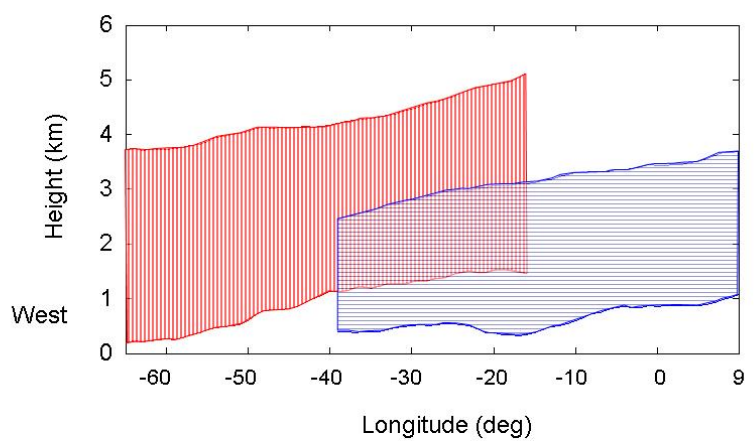

b.

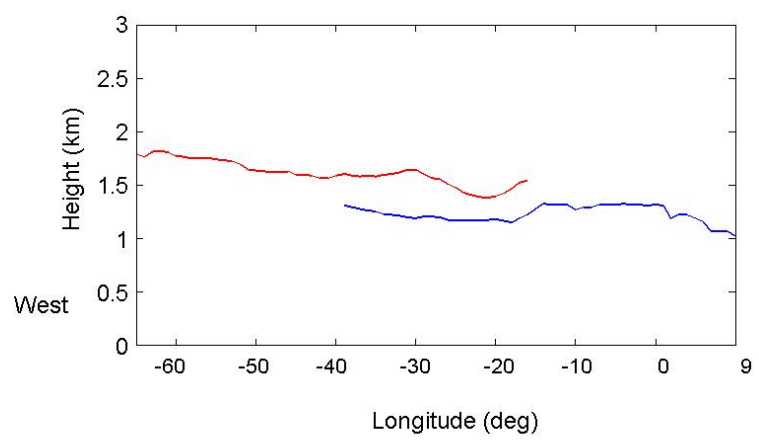

Fig. 5. Results of (a) the average dust height and thickness of the summer (red) and winter (blue) upper plumes, and (b) the average lower dust plumes top heights. Results of plume bases height and thickness (mainly of the lower plumes) may introduce error. Due to the expected error the bases of the lower dust plumes are not presented in Fig. 5b. All averages were calculated along the ROI, and after determination of the best thresholds.

layers top height, it was excluded from the dataset in the next steps of the analysis.

In order to analyze the height distribution of the apparent bi modal distribution, we needed to separate the two modes. The best threshold for separation (after excluding the MBL samples) top heights was determined by looking for the threshold that will show the weakest sensitivity of the average top height to small threshold changes. Namely, we calculated the mean (low and high) dust top height $\left(H_{l}\right.$ and $H_{h}$ ) for a range of thresholds ( $T r$ ) and the best threshold was determined by minimizing the top's height derivatives,

$\operatorname{Tr}=\operatorname{Tr}\left(\min \left\{\frac{d H_{l, h}}{d T r}\right\}\right)$.

From the above distribution analysis, the chosen thresholds for the aerosol average top heights are: 1) an upper aerosol plumes with top height above 2.7 and $1.6 \mathrm{~km}$ in the summer and winter, respectively; 2) a lower aerosol plumes with top height above the MBL $(0.8 \mathrm{~km}$, measured by the MSc height, see Sect. 3.2) in both seasons and top height equal or below 2.7 and $1.6 \mathrm{~km}$ for the summer and winter, respectively.
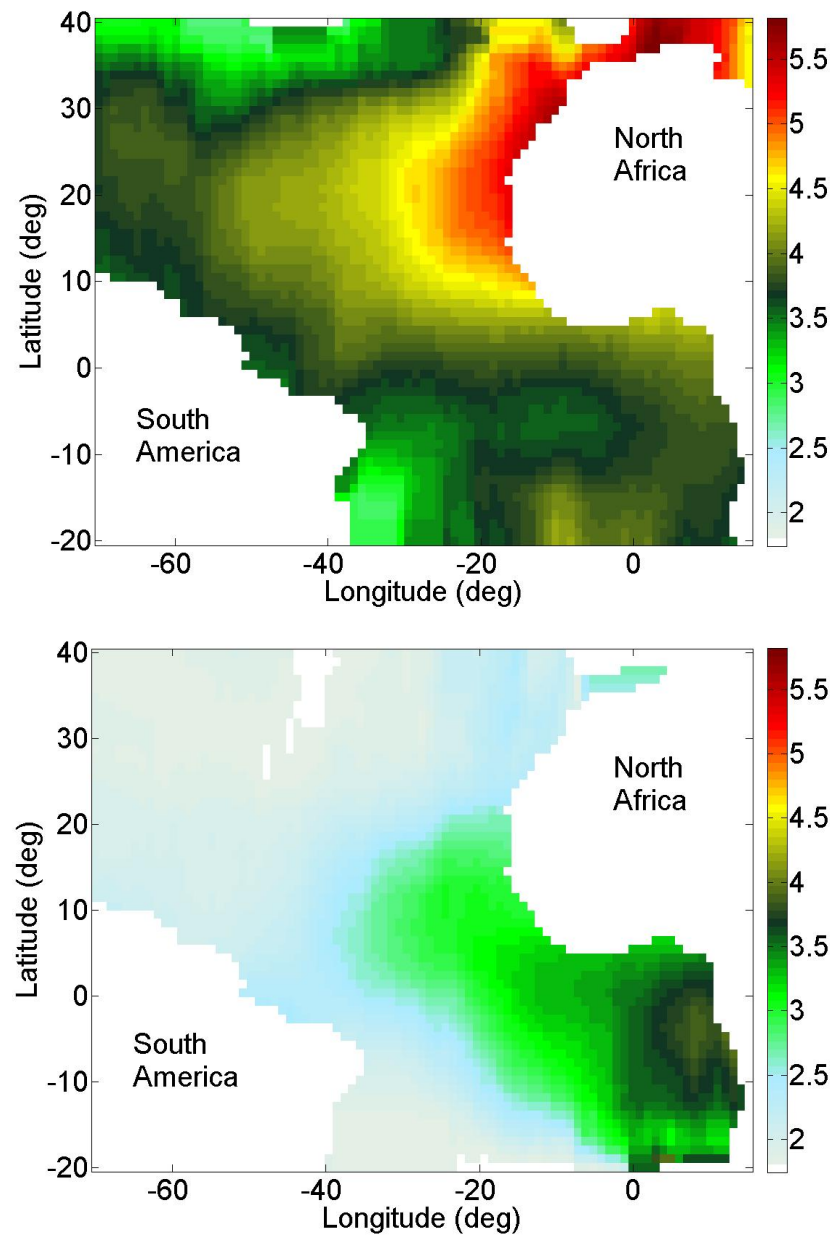

Fig. 6. Averaged seasonal spatial distribution of the upper dust plums top height for the summer (upper panel) and winter (lower panel) seasons; scale height in $\mathrm{km}$.

The analysis of the dust plumes over western parts of the Atlantic Ocean reveals that the separation between the two modes is less clear. Therefore, the Region Of Interest (ROI) was selected to be the first $50^{\circ}$ longitude from the African coastline over the Ocean (along the contours of Fig. 2).

Upper plumes: The dust top height distribution analysis along the longitudinal cross-section of the ROI, (Fig. 5a), shows that during the summer the average top height, when crossing the African coastline, is $5.1 \pm 0.4 \mathrm{~km}$. During the winter the upper dust-smoke plumes are lower and the mean height near the African coastline is $3.7 \pm 0.4 \mathrm{~km}$. As the upper dust plumes are transported westward they decrease in height on an average of $27 \mathrm{~m}$ per $1^{\circ}$ longitude during the summer and $23 \mathrm{~m}$ during the winter. Examination of the upper dust plumes average thickness (calculated as the difference between each plume top height and its corresponding base height along the ROI, Fig. 5a) showed that on average, the upper plumes are significantly thicker during the summer ( 3 to $3.6 \mathrm{~km}$ in the summer, versus 2 to $2.7 \mathrm{~km}$ in the winter). 


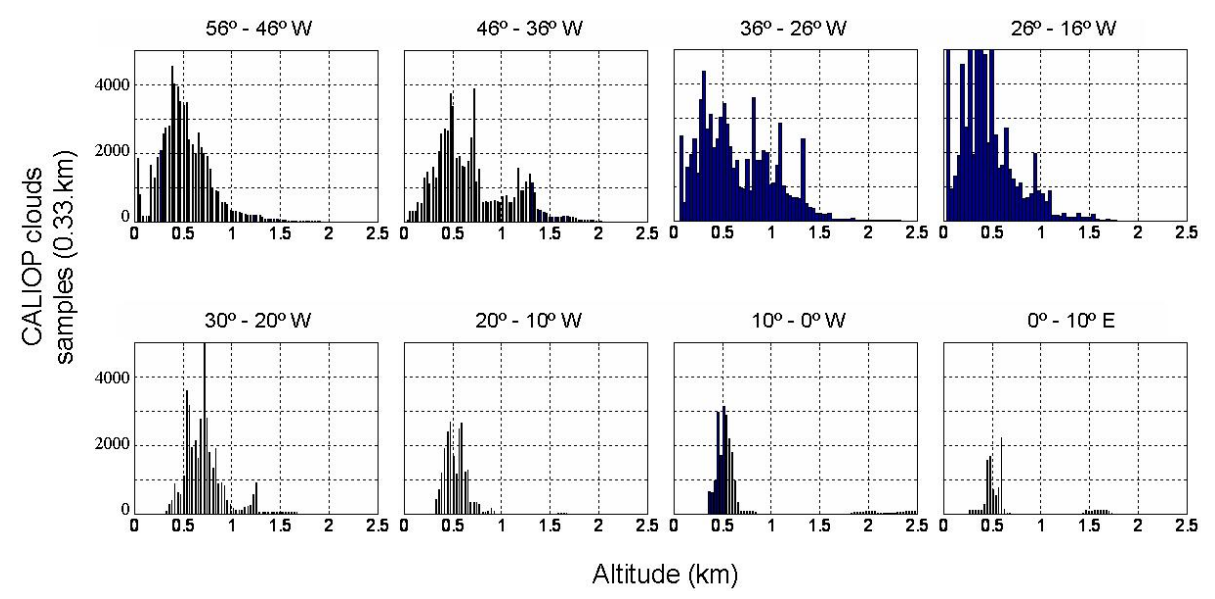

Fig. 7. Clouds top height distribution along the ROI, for the summer (upper panel) and winter (lower panel). Each histogram covers an area of $10^{\circ}$ longitudes along the contour line (marked in Fig. 2), starting from the West North African coastline (right) toward the Americas (left). CALIOP samples covered only low clouds (lower then $2.5 \mathrm{~km}$ ). Samples for horizontal intervals of $330 \mathrm{~m}$ along the flight track.

Lower plumes: Analysis of the lower dust plumes mean top height (along the ROI) shows an inverse trend (Fig. 5b), namely the dust crosses the African coastline near $1.5 \pm 0.25$ and $1.1 \pm 0.35 \mathrm{~km}$ in the summer and winter, respectively, and the average height increases (in an order of a few hundred meters) toward the western side of the Atlantic Ocean (in the winter the trend is less pronounced).

Comparing the seasonal spatial structure of the averaged dust plumes top height (Fig. 6a and b) to the structure of the MODIS AOD measurements over the Atlantic Ocean (Fig. 2, left panel) shows that during the summer, the maximal top height of the upper dust plumes is located north to the maximal AOD. Similar analysis of the winter season reveals that the location of the maximum top height of the dust-smoke plumes is located south to the maximal AOD location. A possible explanation to this difference is the African relief that may serve as an orographic barrier that lifts the transported dust: during the summer it may be the Atlas mountains, located in the north western part of Africa (Morocco, Algeria, and Tunisia), while in the winter the transported dust may be lifted by mount Oku $(3000 \mathrm{~m})$ and mount Cameroon $(4070 \mathrm{~m})$, both located in Cameroon. Note that the MODIS winter fine fraction distribution (Fig. 2, lower right side) shows higher fine fraction values in the southern region suggesting a larger contribution from smoke on the southern part of the average plume.

\subsection{Low stratiform clouds}

The examined clouds were low clouds (including Stratocumulus and Stratus clouds), with top heights lower than $2.5 \mathrm{~km}$. These clouds height distributions along the ROI show a bi-modal distribution in the summer and one dominant mode in the winter season (Fig. 7). This can be interpreted as a separation between the MSc clouds that are bounded by the shallow MBL (as was observed during the sampling stage) and other stratiform clouds. The low MSc clouds height can be used as a proxy to the MBL top height. Like in the dust case, when analyzing the stratiform cloud height, the best threshold for separation between the clouds modes was determined by looking for the threshold that will show the weakest sensitivity of the average clouds mode height to small threshold changes. Based on this analysis the clouds height distribution was divided to two separate modes below and above $0.8 \mathrm{~km}$.

\section{Discussion and conclusions}

In this study we used the CALIOP vertical backscattering profiles to examine the seasonal dust height distribution over the Atlantic Ocean during one boreal summer (2006) and one boreal winter (2006-2007).

During the summer, North African dust transport over the Atlantic Ocean is characterized by two levels of plumes: (a) elevated plumes, mostly separated from the underneath MBL and undercut below by the trade winds, and (b) lower plumes, attached (from above) and most likely within the MBL.

Presumably, the elevated plumes are a result of intensive solar heating of the bright Saharan surface that encourage lifting of dust into the deep mixed boundary layer. As the plumes cross the coastline, they override the cooler and moister maritime air layer (Karyampudi et al., 1999). The lower dust layer may be a result of a combination of fresh emission from costal dust sources toward the ocean at low altitude and sedimentation of dust from upper plumes.

The average base and top heights of the upper dust plumes found in this study agree with results from previous studies (e.g. McConnell., 2008; Myhre et al., 2003) although some deviations exist. 
Towards the western Atlantic Ocean, the apparent vertical structure is less clear, possibly due to descending and sedimentation of the upper layer and the rising of the lower layer (caused possibly by the east-west sea surface temperature gradient and its impact on the marine boundary layer depth).

In situ measurements conducted in the western Atlantic (on the edge of the ROI during the summer) (Reid et al., 2002, 2003; Maring, 2003) showed a chaotic vertical structure of transported dust. However, Reid et al. (2003) showed that over the western Atlantic, the chaotic vertical structure of the transported dust was favored with upper and lower (in the MBL) layers. These finding suggest that our difficulties to track the structure of the dust layers over the western Atlantic, was caused by the method of seasonal averaging because of the changing nature of these layers.

During the winter season, the bi-modal trend is less clear, the dust is advected off the coastline of Africa in lower altitudes compared to the summer. This may be a result of shallower boundary layer and weaker surface heat fluxes over the Sahel, where the dust is emitted towards the ocean during the winter (compared to the Sahara region where it is emitted during the summer). Comparison between the above cited AMMA results (that showed low and high concentration of dust in the lower and higher altitude, respectively) to our winter results, shows that our results may over estimate the height of the bulk part (in mass) of the transported dust.

In situ measurements that represent the winter months (Formenti et al., 2001) showed that the dust may reach South America either in a uniform vertical structure or as several plumes.

Westwards from the studied area (ROI, marked by contours in Fig. 2) we could not distinguish between the two dust layers. We assumed that the aerosols are transported in one dust layer that includes the marine boundary layer, in both seasons (in the winter it is a mixed dust-smoke plume), or in a chaotic vertical structure (not shown in this paper).

The average vertical depth of the summer upper dust plumes is 3 to $3.6 \mathrm{~km}$ with average top height of $5.1 \pm 0.4 \mathrm{~km}$ near the African coast $\left(15^{\circ} \mathrm{W}\right)$. A decrease in height of $27 \mathrm{~m}$ per $1^{\circ}$ longitude yields dust top height of $3.3 \mathrm{~km}$ and a base touching the ocean around $82^{\circ} \mathrm{W}$ (Caribbean Sea).

The winter upper dust and smoke plumes average width is 2 to $2.7 \mathrm{~km}$, with average top height of $3.7 \pm 0.4 \mathrm{~km}$ near the Gulf of Guinea $\left(10^{\circ} \mathrm{E}\right)$. A height slope of $23 \mathrm{~m}$ per $1^{\circ}$ longitude yielding dust-smoke plumes top height of $2.4 \mathrm{~km}$ and a base touching the ocean around $49^{\circ} \mathrm{W}$, near the Amazon.

The average summer lower dust plumes top height near the African coast is $1.5 \pm 0.25 \mathrm{~km}$ and it is $1.1 \pm 0.35 \mathrm{~km}$ in the winter. In both seasons the lower dust plumes top heights slightly increase toward the western side of the Atlantic Ocean.

The stratiform low clouds height analysis showed a bimodal distribution as well. The MSc clouds (bounded by the MBL) contribute to the lower altitude clouds layer at average height of less than $0.8 \mathrm{~km}$. The higher altitude (less common) startiform clouds, appear mostly in the summer. The presence of the lower dust plumes suggests a direct interaction between the clouds and the dust, as their co-existence was observed at the sampling stage. Moreover, on average, the base of the upper dust plumes will reach height of less than $1 \mathrm{~km}$ in longitude of $43^{\circ} \mathrm{W}$ in the summer and longitude $7^{\circ} \mathrm{E}$ in the winter, over the Atlantic Ocean where there are still significant regions covered by MSc cloud fields (Fig. 7).

Acknowledgements. This research was partly funded by the Weizmann-Argentina Cooperation program. I. K. is incumbent of the Benjamin H. Swig and Jack D. Weiler career development chair.

Edited by: M. Petters

\section{References}

Albrecht, B. A.: Aerosols, cloud microphysics, and fractional cloudiness, Science, 245, 1227-1230, 1989.

Ansmann, A., Baars, H., Tesche, M., Müller, D., Althausen, D., Engelmann, R., Pauliquevis, T., and Artaxo, P.: Dust and smoke transport from Africa to South America: Lidar profiling over Cape Verde and the Amazon rainforest, Geophys. Res. Lett., 36, L11802, doi:10.1029/2009GL037923, 2009.

Cakmur, R. V., Miller, R. L., Perlwitz, J., Geogdzhayev, I. V., Ginoux, P., Koch, D., Kohfeld, K. E., Tegen, I., and Zender, C. S.: Constraining the magnitude of the global dust cycle by minimizing the difference between a model and observations, J. Geophys. Res., 111(D6), D06207, doi:10.1029/2005JD005791, 2006.

Carlson, T. N. and Prospero, J. M.:, The large-scale movement of Saharan air outbreaks over the northern equatorial Atlantic, J. Appl. Meteor., 11, 283-297, 1972.

Dubovik, O., Holben, B., Eck, T. F., Smimov, A., Kaufman, Y. J., King, M. D., Tanré, D., and Slutsker, I.: Variability of absorption and optical properties of key aerosol types observed in worldwide locations, J. Atmos. Sci., 59, 590-608, 2002.

Engelstaedter, S., Washington, R., and Tegen, I.: North African dust emissions and transport, Earth-Sci. Rev., 79(1-2), 73-100, 2006.

Falkowski, P. G., Barber, R. T., and Smetacek, V.: Biogeochemical Controls and Feedbacks on Ocean Primary Production, Science, 281, 200-206, 1998.

Formenti, P., Andreae, M. O., Lange, L., Roberts, G., Cafmeyer, J., Rajta, I., Maenhaut, W., Holben, B. N., Artaxo, P., and Lelieveld, J.: Saharan dust in Brazil and Suriname during the LargeScale Biosphere-Atmosphere Experiment in Amazonia (LBA)Cooperative LBA Airborne Regional Experiment (CLAIRE) in March 1998, J. Geophys. Res., 106, 14919-14934, 2001.

Formenti, P., Rajot, J. L., Desboeufs, K., Caquineau, S., Chevaillier, S., Nava, S., Gaudichet, A., Journet, E., Triquet, S., Alfaro, S., Chiari, M., Haywood, J. M., Coe, H., and Highwood, E. J.: Regional variability of the composition of mineral dust from Western Africa: results from the AMMA SOP0/DABEX and DODO, J. Geophys. Res., 113, D00C13, doi:10.1029/2008JD009903, 2008.

Garrison, V. H., Shinn, E. A., Foreman, W. T., Griffin, D. W., Holmes, C. M., Kellogg, C. A., Majewski, M. S., Richardson, 
L. L., Ritchie, K. B., and Smith, G. W.: African and Asian dust: From desert soils to coral reefs, Bioscience, 53, 469-480, 2003.

Generoso, S., Bey, I., Labonne, M., and Bréon, F. M.: Aerosol vertical distribution in dust outflow over the Atlantic: Comparisons between GEOS-Chem and Cloud-Aerosol Lidar and Infrared Pathfinder Satellite Observation (CALIPSO), J. Geophys. Res., 113, D24209, doi:10.1029/2008JD010154, 2008.

Hansen, J., Sato, M., and Ruedy, R.: Radiative forcing and climate response, J. Geophys. Res., 102(D6), 6831-6864, 1997.

Herman, J. R., Bhartia, P. K., Torres, O., Hsu, C., Seftor, C., and Celarier, E.: Global distribution of UV-absorbing aerosols from Nimbus-7/TOMS data, J. Geophys. Res., 102(D6), 6831-6864, 1997.

Haywood, J. and Boucher, O.: Estimates of the direct and indirect radiative forcing due to tropospheric aerosols: a review, Rev. Geophys., 38, 513-543 2000.

IPCC: Climate Change 2007: The Scientific Basis, Contribution of Working Group I to the fourth Assessment Report of the Intergovernmental Panel on Climate Change, edited by: Solomon, S., Qin, D., Manning, M., Chen, Z., Marquis, M., Averyt, K. B., Tignor, M., and Miller, H. L., Cambridge University Press, Cambridge, United Kingdom and New York, NY, USA, 996 pp., 2007.

Israelevich, P. L., Levin, Z., Joseph, J. H., and Ganor, E.: Desert aerosol transport in the Mediterranean region as inferred from the TOMS aerosol index, J. Geophys. Res., 107(D21), 4572, doi:10.1029/2001JD002011, 2002.

Johnson, B. T., Osborne, S. R., Haywood, J. M., and Harrison, M. A. J.: Aircraft measurements of biomass burning aerosol over West Africa during DABEX, J. Geophys. Res., 113, D00C12, doi:10.1029/2008JD009848, 2008a.

Johnson, B. T., Heese, B., McFarlane, S. A., Chazette, P., Jones, A., and Bellouin, N.: Vertical distribution and radiative effects of mineral dust and biomass burning aerosol over west Africa during DABEX, J. Geophys. Res., 113, D00C12, doi:10.1029/2008JD009848, 2008b.

Kalu, A. E.: The African dust plume: Its characteristics and propagation across west Africa in winter, SCOPE, 14, 95-118, 1979.

Karyampudi, V. M. and Carlson, N. T.: Analysis and numerical simulations of the Saharan Air Layer and its effect on easterly wave disturbances, J. Atmos. Sci., 45(21), 3102-3136, 1988.

Karyampudi, V. M., Palm, S. P., Reagen, J. A., Fang, H., Grant, W. B., Hoff, R. M., Moulin, C., Pierce, H. F., Torres, O., Browell, E. V., and Melfi, S. H.: Validation of the Saharan dust plume conceptual model using lidar, Meteosat and ECMWF, B. Am. Meteorol. Soc., 80, 1045-1075, 1999.

Kaufman, Y. J., Tanre, D., and Boucher, O.: A satellite view of aerosols in the climate system, Review, Nature, 419, 215-223, 2002.

Kaufman, Y. J., Koren, I., Remer, L. A., Rosenfeld, D., and Rudich, Y.: The Effect of Smoke, Dust and Pollution Aerosol on Shallow Cloud Development Over the Atlantic Ocean, Proceedings of the National Academy of Sciences, 102(32), 11207-11212, 2005a.

Kaufman, Y. J., Koren, I., Remer, L. A., Tanre, D., Ginoux, P., and Fan, S.: Dust transport and deposition observed from the Terra-Moderate Resolution Imaging Spectroradiometer (MODIS) spacecraft over the Atlantic Ocean, J. Geophys. Res., 110, D10S12, doi:10.1029/2003JD004436, 2005 b.

Kaufman, Y. J., Boucher, O., Tanre, D., Chin, M., Remer, L.
A., and Takemura, T.: Aerosol anthropogenic component estimated from satellite data. Geophys. Res. Lett., 32, L17804, doi:10.1029/2005GL023125, 2005c.

Koren, I., Kaufman, Y. J., Rosenfeld, D., Remer, L. A., and Rudich, Y.: Aerosol invigoration and restructuring of Atlantic convective clouds, Geophys. Res. Lett., 32, LI4828, doi:10.1029/2005GL023187, 2005.

Koren, I., Kaufman, Y. J., Washington, R., Todd, C. C., Rudich, Y., Martins, J. V., and Rosenfeld, D.: The Bod'el'e depression: a single spot in the Sahara that provides most of the mineral dust to the Amazon forest, Environ. Res., 1, 1-5, 2006.

Levin, Z., Ganor, E., and Gladstein, V.: The effects of desert particles coated with sulfate on rain formation in the eastern Mediterranean, J. Appl. Meteor., 35, 1511-1523, 1996.

Liu, Z., Omar, A., Vaughan, M., Hair, J., and Kittaka, C.: CALIPSO lidar observations of the optical properties of saharan dust: A case study of long-range transport, 113, D07207, doi:10.1029/2007JD008878, 2008a.

Liu, Z., Liu, D., Huang, J., Vaughan, M., Uno, I., Sugimoto, N., Kittaka, C., Trepte, C., Wang, Z., Hostetler, C., and Winker, D.: Airborne dust distributions over the Tibetan Plateau and surrounding areas derived from the first year of CALIPSO lidar observations, Atmos. Chem. Phys., 8, 5045-5060, 2008b, http://www.atmos-chem-phys.net/8/5045/2008/.

Maring, H., Savioe, D. L., Izaguirre, M. A., Custals, L., and Reid, J. S.: Vertical distributions of dust and sea-salt aerosols over Puerto Rico during PRIDE measured from a light aircraft, J. Geophys. Res., 108(D19), 8587, doi:10.1029/2002JD002544, 2003.

McConnell, C. L., Highwood, E. J., Coe, H., Formenti, P., Anderson, B., Osborne, S., Nava, S., Desboeufs, K., Chen, G., and Harrison, M. A. J.: Seasonal variations of the physical and optical characteristics of Saharan dust: Results from the Dust Outflow and Deposition to the Ocean (DODO) experiment, J. Geophys. Res., 113, D14S05, doi:10.1029/2007JD009606, 2008.

Middleton, N. J. and Goudie, A. S.: Saharan dust: sources and trajectories, Transactions of the Institute of British Geographers, 26(2), 165-181, 2001.

Myhre, G., Grini, A., Haywood, J. M., Stordal, F., Chatenet, B., Tanré, D., Sundet, J. K., and Isaksen, I. S. A.: Modeling the radiative impact of mineral dust during the Saharan Dust Experiment (SHADE) campaign, J. Geophys. Res., 108(D18), 8579, doi:10.1029/2002JD002566, 2003.

Prospero, J. M. and Carlson, T. N.: Vertical and areal distribution of Saharan dust over the western equatorial North Atlantic ocean, J. Geophys. Res., 77, 5255-5265, 1972.

Prospero, J. M. and Nees, R. T.: Dust concentration in the atmosphere of the equatorial North Atlantic: Possible relationship to the Sahelian drought, Science, 196, 1196-1198, doi:10.1126/science.196.4295.1196, 1977.

Prospero, J. M.: Long-range transport of mineral dust in the global atmosphere: impact of African dust on the environment of Southeastern United States, Proc. Natl. Acad. Sci., 96, 3396-3403, 1999.

Prospero, J. M., Ginoux, P., Torres, O., Nicholson, S. E., and Gill, T. E.: Environmental characterization of global sources of atmospheric soil dust identified with the NIMBUS 7 total ozone mapping spectrometer (TOMS) absorbing aerosol product, Rev. Geophys., 40(1002), 2-1-2-31,, 2002.

Prospero, J. M. and Lamb, J. P.: African droughts and dust trans- 
port to the Caribbean: Climate change and implications, Science, 302, 1024-1027, 2003.

Psenner, R.: Living in a dusty world: airborne dust as a key factor for alpine lakes, Water Air Soil Poll., 112(3-4), 217-227, 1999.

Ramanathan, V., Crutzen, P. J., Kiehl, J. T., and Rosenfeld, D.: Aerosols, climate, and the hydrological cycle, Science, 294, 2119-2124, 2001.

Reichholf, J. H.: Is Saharan dust a major source of nutrients for the Amazonian rain forest?, Studies on Neotropical Fauna and Environment, 21(4), 251-255, 1986.

Reid, J. S., Westphal, D. L., Livingston, J. M., Savoie, D. L., Maring, H. B., Jonsson, H. H., Eleuterio, D. P., Kinney, J. E., and Reid, E. A.: Dust vertical distribution in the Caribbean during the Puerto Rico Dust Experiment, Geophys. Res. Lett., 29(7), 1151, doi:10.1029/2001GL014092, 2002.

Reid, J. S., Kinney, J. E., Westphal, D. L., Holben, B. N., Welton, E. J., Tsay, S., Eleuterio, D. P., Campbell, J. R., Christopher, S. A., Colarco, P. R., Jonsson, H. H., Livingston, J. M., Maring, H. B., Meier, M. L., Pilewskie, P., Prospero, J. M., Reid, E. A., Remer, L. A., Russell, P. B., Savoie, D. L., Smirnov, A., and Tanré, D.: Analysis of measurements of Saharan dust by airborne and ground-based remote sensing methods during the Puerto Rico Dust Experiment (PRIDE), J. Geophys. Res., 108(D19), 8586, doi:10.1029/2002JD002493, 2003.

Schepanski, K., Tegen, I., and Macke, A.: Saharan dust transport and deposition towards the tropical northern Atlantic, Atmos. Chem. Phys., 9, 1173-1189, 2009, http://www.atmos-chem-phys.net/9/1173/2009/.
Swap, R., Garstang, M., Greco, S., Talbot, R., and Kallberg, P.: Saharan dust in Amazon basin, Tellus 44B, 133-149, 1992.

Tegen, I.: Modeling the mineral dust aerosol cycle in the climate system, Quat. Sci. Rev., 22(19), 1821-1834, 2003.

Thomason, L. W., Pitts, M. C., and Winker, D. M.: CALIPSO observations of stratospheric aerosols: a preliminary assessment, Atmos. Chem. Phys., 7, 5283-5290, 2007, http://www.atmos-chem-phys.net/7/5283/2007/.

Twomey, S.: Pollution and the planetary albedo, Atmos. Environ., 8, 1251-1256, 1974.

Vaughan, M. A., Winker, D. M., and Powell, K. A.: CALIOP Algorithm Theoretical Basis Document, Part 2: Feature Detection and Layer Properties Algorithms, available at: http://www-calipso. larc.nasa.gov/resources/pdfs/PC-SCI-202_Part2_rev1x01.pdf, 2005.

Winker, D. M., Hunt, W. H., and McGill, M. J.: Initial performance assessment of CALIOP, Geophys. Res. Lett., 34, L19803, doi:10.1029/2007GL030135, 2007.

Yu, H., Kaufman, Y. J., Chin, M., Feingold, G., Remer, L. A., Anderson, T. L., Balkanski, Y., Bellouin, N., Boucher, O., Christopher, S., DeCola, P., Kahn, R., Koch, D., Loeb, N., Reddy, M. S., Schulz, M., Takemura, T., and Zhou, M.: A review of measurement-based assessments of the aerosol direct radiative effect and forcing, Atmos. Chem. Phys., 6, 613-666, 2006, http://www.atmos-chem-phys.net/6/613/2006/. 